\title{
Efeito do congelamento e do tempo de armazenamento do soro sanguíneo de cordeiros na determinação de parâmetros bioquímicos
}

\section{Effect of freezing and storage time of blood serum of lambs in the determination of biochemical parameters}

\author{
Fernanda Schoma de Oliveira ${ }^{\text {* }}$; Margarete Kimie Falbo $^{2}$; Itacir Eloi Sandini; \\ Larissa Emi Ishiy ${ }^{4}$
}

\section{Resumo}

Este trabalho teve como objetivo avaliar o efeito do congelamento $\left(-20^{\circ} \mathrm{C}\right)$ e o tempo de armazenamento do soro na determinação de valores bioquímicos em ovinos. Foi realizado na Universidade Estadual do Centro-Oeste em Guarapuava - PR. O soro foi obtido de 32 cordeiros da raça Ile de France x Corriedale, com 4 meses de idade. Foram realizadas análises, imediatamente após a obtenção da amostra, tempo zero e após 7, 14, 21, 28 dias da colheita do sangue. Os analitos testados foram aspartato-amino-transferase (AST), uréia, proteína total, colesterol, fósforo e magnésio. Os resultados permitiram concluir que o tempo de armazenamento das amostras congeladas $\left(-20^{\circ} \mathrm{C}\right)$ causou alterações nos resultados para as análises de proteína total, fósforo, e magnésio. As determinações séricas AST, colesterol e uréia não diferiram estatisticamente nos diferentes tempos de armazenamento.

Palavras-chave: Estabilidade do soro. Cordeiros. Tempo de armazenamento.

\begin{abstract}
This study aimed to evaluate the effect of freezing $\left(-20^{\circ} \mathrm{C}\right)$ and time of storage of serum in the determination of biochemical values in sheep. It was held at the Universidade Estadual do Centro-Oeste in Guarapuava - PR. The serum was obtained from 32 Corriedale x Ille de France crossbred lambs, four months old. Nine hundred and sixty tests were performed, the first immediately after sampling (time zero), after 7, 14, 21, 28 days after blood collection. The analytes tested were aspartate aminotranferase (AST), urea, total protein, cholesterol, phosphorus and magnesium. The results showed that the time of storage of frozen samples $\left(-20^{\circ} \mathrm{C}\right)$ was able to alter results of total protein, phosphorus, and magnesium. The serum measurements of AST, cholesterol and urea did not differ in different storage times.

Key words: Serum stability. Sheeps. Time of storage.
\end{abstract}

1 Médica Veterinária, Programa Universidade Sem Fronteiras, SETI, PR. Rua Silvas do Brasil, 450. Vila Beraldo. Prudentópolis, PR. 84400-000. E-mail: fernandaschoma@hotmail.com

2 Prof ${ }^{\mathrm{a}}$. da Universidade Estadual do Centro Oeste, Departamento Medicina Veterinária, UNICENTRO. E-mail:margaretefalbo@ hotmail.com

3 Prof. da Universidade Estadual do Centro Oeste, Departamento Agronomia, UNICENTRO. E-mail:isandini@hotmail.com

4 Acadêmica do Curso de Medicina Veterinária da Universidade Estadual do Centro Oeste. E-mail:larissaishiy@hotmail.com

* Autor para correspondência 


\section{Introdução}

Os exames bioquímicos, realizados a partir do soro e plasma sanguíneos são importantes ferramentas para auxiliar no diagnóstico de enfermidades que acometem os animais domésticos (KANEKO; HARVEY; BRUSS, 1997). O perfil bioquímico funciona como indicador do metabolismo protéico, energético e mineral, além de apontar possíveis alterações do funcionamento hepático, renal, pancreático, ósseo, muscular, cardíaco, do sistema nervoso central e do trato gastrointestinal (GONZÁLEZ; SILVA, 2003).

Outros fatores como dieta, atividade física do animal e características ambientais como temperatura, altitude, solo e umidade do ar podem interferir nos resultados (MUNDIM et al., 2004). Davy, Jackson e Walker (1984) destacaram aspectos relacionados à metodologia e à amostra utilizada, além da espécie animal, como variáveis que podem influenciar nas condições ideais de conservação da amostra. Condições de armazenamento são fatores conhecidos por afetar os níveis aferidos, mas os relatos não são consistentes, e variam de decréscimo, não alteração ou acréscimo (DEVANAPALLI et al., 2002).

Em grandes estudos epidemiológicos ou clínicos, as amostras são muitas vezes colhidas, armazenadas e analisadas posteriormente. O tempo de armazenamento pode variar de dias a meses ou mesmo anos, e a temperatura também pode oscilar durante o período de armazenamento; isso ocorre por que muitas vezes torna-se inviável realizar as análises logo após a colheita, especialmente em animais de produção. Na medicina veterinária até agora, pouco tem sido publicado sobre a estabilidade do sangue total e de muitos marcadores bioquímicos (DEVANAPALLI et al., 2002; EHSANI, et al., 2008).

Em trabalho realizado por Fernandes, Teixeira e Santos (2001) utilizando 928 análises de soro e plasma canino, verificaram que o soro sanguíneo tem maior estabilidade do que o plasma em todas as condições de estoque estabelecidas.

De acordo com Russel e Roussel (2007), a estabilidade dos analitos varia, mas a maioria é estável em temperatura de refrigeração $\left(4{ }^{\circ} \mathrm{C}\right)$ por 24 a 36 horas, e, se um prazo mais longo for necessário antes que a amostra possa ser processada, o soro pode ser congelado a $-20^{\circ} \mathrm{C}$, pois o congelamento tem míninos efeitos sobre a maioria dos analitos. Entretanto, vários congelamentos e descongelamentos de uma amostra devem ser evitados, pois isso afeta a estabilidade de várias substâncias, especialmente as enzimas.

Desta forma, este trabalho teve como objetivo avaliar a influência do tempo de armazenamento em temperatura de $20{ }^{\circ} \mathrm{C}$, de amostras de soro de cordeiros na determinação sérica de aspartato amino transferase (AST), uréia, proteína total, colesterol, fósforo e magnésio.

\section{Material e Métodos}

Este trabalho foi realizado na Universidade Estadual do Centro-Oeste, em Guarapuava PR, Campus CEDETEG, localizado na região fisiográfica denominada de Terceiro Planalto Paranaense.

Foram utilizados 32 cordeiros, hígidos, com 4 meses de idade, fêmeas, mestiços do cruzamento Corriedale $\mathrm{x}$ Ile de France, mantidos em pastagem de aveia branca (Avena sativa L.) e azevém anual (Lollium multiflorum Lam.), com água e sal mineral a vontade. Amostras de sangue foram colhidas da veia cefálica, em frascos estéreis sem anticoagulante e encaminhadas ao Laboratório de Patologia Clínica Veterinária da Unicentro, onde foram centrifugadas a $2500 \mathrm{rpm}$ por 10 minutos para obtenção do soro. O soro de cada animal foi separado em 6 alíquotas, acondicionadas em eppendorfs e identificadas, sendo que a alíquota identificada como tempo zero foi processada logo após a centrifugação das amostras. As outras alíquotas foram colocadas no freezer de refrigerador com freezer independente de 
sistema de descongelamento do tipo "frost free", a $20{ }^{\circ} \mathrm{C}$ até o processamento das amostras após 7,14 , 21, 28 dias. Os parâmetros analisados foram: AST pelo método cinético (Labtest-catálogo 75), uréia CE pelo método cinético (Labtest - catálogo 27), proteína total método cinético (Labtest - catálogo 18), colesterol modo cinético (Labtest - catálago 60), fósforo, método cinético (Labtest catálogo 42) e magnésio pelo método de reacão de ponto final (Labtest-catálogo 50). As análises laboratoriais foram determinadas em analisador bioquímico semi-automático (BIOPLUS 200 ${ }^{\circledR}$ ).

Os dados obtidos foram submetidos á análise da variância e as médias comparadas entre si pelo teste de Tukey a $5 \%$ de probabilidade pelo programa de análise estatística SISVAR.

\section{Resultados e Discussão}

Verificou-se que ao longo do tempo de armazenamento, sob temperatura de $-20{ }^{\circ} \mathrm{C}$ não houve diferença significativa na determinação da enzima AST. Comis (2006) verificando a estabilidade desta enzima em equinos não observou alterações de estabilidade do soro mantido nas mesmas condições de temperatura $\left(-20^{\circ} \mathrm{C}\right)$ após 30 , 60, 90 e 180 dias. González e Silva (2003) relataram que a temperatura de armazenamento pode causar instabilidade deste analito por comprometer a atividade desta enzima, já que a mesma possui meia vida em torno de 18 horas em temperatura ambiente. Com os resultados encontrados neste trabalho, para enzima AST, é possível inferir que este analito é estável por 28 dias em amostras de soro de cordeiros congeladas a $-20{ }^{\circ} \mathrm{C}$.

Quanto à dosagem do colesterol, este também não apresentou diferença significativa nos períodos de armazenamento e congelamento, porém não foi encontrados relatos sobre a estabilidade e tempo de armazenamento deste analito para espécie ovina. Em um trabalho realizado por Kuchmak, Taylor e Olanski (1982) com a espécie humana não encontrou alterações em amostras de soro congeladas a $-20{ }^{\circ} \mathrm{C}$ por cinco anos.

Os níveis de uréia sérica também não apresentaram diferença estatística significativa sendo o mesmo observado por Fernandes, Teixeira e Santos (2001) utilizando soro mantido a $-20{ }^{\circ} \mathrm{C}$ por até 60 dias para a espécie canina. Em bovinos Wittwer, Bohnwald e Klaasen (1986) relataram estabilidade do soro mantido a $-25^{\circ} \mathrm{C}$ por 12 meses, e Doretto (1996) em soro mantido entre $-5 \mathrm{e}-20^{\circ} \mathrm{C}$ por até 90 dias.

Para as análises de Proteína Total (PT) houve diferença significativa entre a primeira análise (Tzero) e os outros períodos avaliados após congelamento a $20{ }^{\circ} \mathrm{C}$ e mostraram-se aumentadas quando comparadas ao soro fresco. Estudo realizado por Comis (2006) com soro sanguíneo de equinos, também revelou aumento deste analito após 30 dias de congelamento nas mesmas condições de temperatura a $-20{ }^{\circ} \mathrm{C}$, além disso, encontrou valores diminuídos 60 e 90 dias, porém mesmo com as variações entre os tempos de congelamento as médias mantiveram-se dentro dos valores de referência, corroborando com os resultados encontrados neste trabalho para espécie ovina. Kaneko, Harvey e Bruss (1997) e Thoresen et al. (1995) também afirmaram que a armazenagem não interfere nos níveis de proteínas totais por até 240 dias quando mantidos a $-20^{\circ} \mathrm{C}$ e $-70{ }^{\circ} \mathrm{C}$, já que mesmo havendo oscilações estes se mantém dentro dos valores de referência.

Quanto aos resultados encontrados para a dosagem sérica de magnésio verificou-se que houve oscilação dos valores analisados no tempo zero (T0) e após os tempos de armazenamento e congelamento, mostrando diferenças estatísticas significativas. Comis (2006) constatou estabilidade do mineral magnésio por até 180 dias em soros de equinos congelados a $20^{\circ} \mathrm{C}$. Portanto, outros estudos serão necessários relacionando à metodologia utilizada e a espécie animal, variáveis que podem influenciar na determinação dos resultados.

Quanto às análises séricas para o fósforo, não 
houve diferença significativa entre os tempos de Ehsani et al. (2008) com soro bovino armazenado armazenamento avaliados, o mesmo verificado por $\quad \mathrm{a}-20^{\circ} \mathrm{C}$ por até 24 horas.

Tabela 1. Médias e coeficiente de variação das dosagens séricas de AST, uréia, proteína total(PT), colesterol, fósforo (P) e magnésio (Mg) nos diferentes tempos: 0 (T0), 7(T1), 14 (T2) 21 (T3) e 28 dias (T4) após congelamento a $-20^{\circ} \mathrm{C}$.

\begin{tabular}{|c|c|c|c|c|c|c|}
\hline Período & $\begin{array}{l}\text { AST } \\
\text { U/L } \\
\end{array}$ & $\begin{array}{l}\text { Uréia } \\
\text { mg/dL }\end{array}$ & $\begin{array}{l}\text { PT } \\
\text { g/ dL } \\
\end{array}$ & $\begin{array}{c}\text { Colesterol } \\
\text { mg/dL } \\
\end{array}$ & $\begin{array}{c}P \\
\mathrm{mg} / \mathrm{dL}\end{array}$ & $\begin{array}{c}\mathrm{Mg} \\
\mathrm{mg} / \mathrm{dL}\end{array}$ \\
\hline T0 & $166,25 \mathrm{~ns}$ & $62,66 \mathrm{~ns}$ & $5,70 \mathrm{~b}$ & $47,59 \mathrm{~ns}$ & $6,33 \mathrm{a}$ & $2,01 \mathrm{~b}$ \\
\hline $\mathrm{T} 1$ & 152,09 & 70,06 & $6,32 \mathrm{a}$ & 60,16 & NA & $2,41 \mathrm{a}$ \\
\hline $\mathrm{T} 2$ & 158,03 & 67,31 & $6,83 \mathrm{a}$ & 52,56 & $6,21 \mathrm{a}$ & $1,44 \mathrm{c}$ \\
\hline $\mathrm{T} 3$ & 154,09 & 60,94 & $6,27 \mathrm{a}$ & 62,03 & $6,82 \mathrm{a}$ & $1,99 \mathrm{~b}$ \\
\hline $\mathrm{T} 4$ & 152,66 & 59,37 & $6,62 \mathrm{a}$ & 60,34 & $6,64 \mathrm{a}$ & $2,27 \mathrm{ab}$ \\
\hline Média & 156,62 & 64,07 & 6,35 & 56,89 & 6,22 & 2,02 \\
\hline CV (\%) & 47,15 & 25,18 & 12,92 & 78,12 & 19,47 & 23,14 \\
\hline
\end{tabular}

ns = Não significativo; NA = Período não analisado.

Médias seguidas pela mesma letra nas colunas não diferem entre si pelo Teste de Tukey $(P>0,05)$.

\section{Conclusão}

Os analitos AST, uréia e colesterol mantiveramse estáveis a - $20{ }^{\circ} \mathrm{C}$ nos tempos $0,7,14,21$ e 28 dias após armazenamento.

As dosagens de fósforo sérico mantiveram-se estáveis a $-20{ }^{\circ} \mathrm{C}$ nos tempos $0,14,21$ e 28 dias.

A proteína total e o magnésio não apresentaram estabilidade em todos os tempos de armazenamento à $-20^{\circ} \mathrm{C}$.

\section{Referências}

COMIS, M. B. Influência do tempo e temperatura sobre a estabilidade do soro e plasma sanguíneos de equinos Mangalarga marchador. 2006. Tese (Dissertação PósGraduação em Medicina Veterinária) - Universidade Federal de Viçosa, Viçosa.

DAVY, C. W.; JACKSON, M. R.; WALKER, J. M. Stabilities of some constituents of marmoset (Callithrix jacchus) plasma unde various conditions of storage. Clinical Chemistry, Standford, v. 30, n. 1, p. 101-104, 1984.

DEVANAPALLI, B.; BERMINGHAM, M. A.;
MAHAJAN, D. Effect of long-term storage at $-80{ }^{\circ} \mathrm{C}$ on the various lipid parameters in stored plasma samples. Clinica Chimica Acta, Charlottesville, v. 3, n. 322, p. 179-181, 2002.

DORETTO, J. S. Influência do tempo e da temperatura de armazenagem sobre a estabilidade de alguns constituintes do soro sangüíneo de bovinos.1996. Dissertação (Mestrado em Patologia Animal) Universidade Estadual Paulista. Faculdade de Ciências Agrárias Veterinárias da UNESP, Jaboticabal.

EHSANI, A.; AFSHARI, A.; BAHADORI, H.; MOHRI, M.; SEIFI, H. A. Serum constituents analyses in dairy cows: efects of duration and temperature of the storage of clotted blood. Research in Veterinary Science, Bridgwater, v. 85, n. 3, p. 473-475, 2008.

FERNANDES, S. T.; TEIXEIRA, M. N.; SANTOS, E. S. Influência da temperatura e do tempo de armazenamento nas dosagens bioquímicas de uréia e creatinina em soro ou plasma caninos. Arquivo Brasileiro de Medicina Veterinária e Zootecnia, Belo Horizonte, v. 53, n. 6, p. 648-651, 2001.

GONZÁLEZ, F .H. D.; SILVA, S. C. Introdução à bioquímica clínica veterinária. Porto Alegre: UFRGS, 2003. $198 \mathrm{p}$.

KANEKO, J. J.; HARVEY, J. W.; BRUSS, M. L. Clinical biochemistry of domestic animals. 5. ed. San Diego: 
Academic Press, 1997, 932 p.

KUCHMAK, M.; TAYLOR, L.; OLANSKI, A. S. Suitability of frozen and lyophilized reference sera for cholesterol and triglyceride determinations. Clinica Chimica Acta, Charlottesville, v. 120, n. 2, p. 261-271, 1982.

MUNDIM, A. V.; TEIXEIRA, A. A.; GALO, J. A.; CARVALHO, F. S. R. Perfil bioquímico e osmolaridade sanguínea de equinos utilizados para trabalho em centros urbanos. Bioscience Journal, Uberlândia, v. 20, n. 1, p. 135-142, 2004.

RUSSEL, K. E.; ROUSELL, A. J. Evaluation of the ruminant serum chemistry profile. Veterinary clinics of North America: Food Animal Practice, College of Veterinary Medicine and Biomedical Sciences, Texas A\&M University, Texas, v. 23, n. 3, p. 403-426. 2007.

THORESEN, S. I.; TVERDAL, A.; HAVRE, G.; MORBERG, H. Effects of storage time and freezing temperature on clinical chemical parameters from canine serum and heparinized plasma. Veterinary Clinical Pathology, Madison, v. 24, n. 4, p. 129-133, 1995.

WITTWER, F.; BOHNWALD, H.; KLAASEN, R. Efecto del tiempo, temperatura de conservacion y del anticoagulante (EDTA/NaF) en muestras para perfiles metabolicos. Archivos de Medicina Veterinária, Facultad de Ciencias Veterinarias. Universidade Austral do Chile. Valdivia, v. 18, n. 1, p. 43-51, 1986. 
